\title{
Evaluation of ingesting Dyma-Burn Xtreme, a thermogenic dietary supplement, on hemodynamic and ECG responses in healthy, young males and females
}

\author{
Craig Jones', Sara Hayward', Stacie Urbina', Cliffa Foster ${ }^{1}$, Shawn Wells², Rob Wildman², Bill Campbell ${ }^{3}$, \\ Lem Taylor ${ }^{1}$, Colin Wilborn ${ }^{1 *}$
}

From International Society of Sports Nutrition: 9th Annual ISSN Conference and Expo Clearwater, FL, USA. 22-23 June 2012

\section{Background}

Ingestion of caffeine is traditionally thought to acutely elevate both blood pressure and heart rate based on the stimulatory properties that it exerts on both the central and peripheral nervous systems, and this effect is primarily dependent on the dose as well as an individual's sensitivity to caffeine. The purpose of this study was to evaluate the safety of the ingestion of a proprietary thermogenic dietary supplement, including the ingredients caffeine, green tea extract, raspberry ketones, and L-Carnitine on ECG and hemodynamic responses.

\section{Methods}

In a double-blind, crossover design 6 male $(\mathrm{N}=6,23.6$ \pm 5.8 years, $180.5 \pm 6.0 \mathrm{~cm}, 89.7 \pm 7.1 \mathrm{~kg}, 16.5 \pm 7.1 \%$ $\mathrm{BF})$ and 6 female $(\mathrm{N}=6,21.3 \pm 3.8$ years, $162.0 \pm 6.0$ $\mathrm{cm}, 64.1 \pm 7.4 \mathrm{~kg}, 28.8 \pm 7.6 \% \mathrm{BF})$ moderate caffeine users $(<200 \mathrm{mg} /$ day $)$ reported to the lab on a 12 hour fast and had a baseline heart rate (HR), blood pressure (SBP and DBP), and ECG variables (RR interval, PR interval, QRS duration, and QT interval) were assessed. Subjects consumed either a 2 capsule serving of DymaBurn Xtreme (DBX) or placebo (PLC) and had HR, SBP/DBP assessed at the end of each hour; and assessed ECG variables in a supine position at 1 hour (1HR), 2 hour (2HR), 3 hour (3HR), and 4 hour (4HR) post consumption. All data was analyzed utilizing a 2x5 ANOVA

\footnotetext{
* Correspondence: cwilborn@umhb.edu

'University of Mary Hardin-Baylor, Human Performance Lab, Belton, TX 76513, USA

Full list of author information is available at the end of the article
}

and one-way ANOVAs were used in the case of a significant interaction. A significance value of 0.05 was adopted throughout.

\section{Results}

No significant $(\mathrm{p}<0.05)$ time or group $\mathrm{x}$ time interaction effects were observed for SBP, DBP, and HR. SBP delta responses (DBX vs. PLC) from baseline are as followed: $1 \mathrm{HR}(12.4 \pm 11.8$ vs. $1.75 \pm 10.4 \mathrm{mmHg}), 2 \mathrm{HR}(10.0 \pm 14.0$ vs. $0.0 \pm 7.9 \mathrm{mmHg}), 3 \mathrm{HR}(13.5 \pm 22.4$ vs. $-2.5 \pm 8.1$ $\mathrm{mmHg})$, and $4 \mathrm{HR}(8.3 \pm 10.5$ vs. $1.5 \pm 10.6 \mathrm{mmHg})$. Delta responses from baseline for DBP are as followed (DBX vs. PLC): 1 HR ( $4.8 \pm 7.4$ vs. $0.6 \pm 7.9 \mathrm{mmHg}), 2 \mathrm{HR}(-0.25 \pm$ 13.2 vs. $-1.0 \pm 7.2 \mathrm{mmHg}), 3 \mathrm{HR}(6.7 \pm 20.9$ vs. $-4.5 \pm 10.1$ $\mathrm{mmHg})$, and $4 \mathrm{HR}(1.25 \pm 6.8$ vs. $1.1 \pm 11.0 \mathrm{mmHg})$. The observed delta responses for HR are as followed (DBX vs. PLC): $1 \mathrm{HR}(-3.0 \pm 6.2$ vs. $-2.5 \pm 5.5 \mathrm{bpm}), 2 \mathrm{HR}(-2.9 \pm 6.5$ vs. $-1.0 \pm 10.0 \mathrm{bpm}), 3 \mathrm{HR}(-2.3 \pm 5.6$ vs. $-0.5 \pm 8.7 \mathrm{bpm})$, and 4 HR $(-1.4 \pm 6.8$ vs. $-0.3 \pm 7.4 \mathrm{bpm})$. No significant $(\mathrm{p}<0.05)$ group or time differences were observed for ECG intervals (RR, PR, and QT) and QRS duration. Additionally, no observed changes in ECG rate and rhythm abnormalities (i.e., PVCs, arrhythmias, etc.) were seen across any time points.

\section{Conclusion}

Acute ingestion of DBX had no significant effects on hemodynamic function and various ECG intervals over the four-hour observation period in daily caffeine users. The stimulatory effects that traditionally occur following caffeine ingestion was not observed, which could be 
explained by a decreased sensitivity to caffeine from regular consumption.

\section{Acknowledgements}

This study was funded by Dymatize Nutrition.

\section{Author details}

'University of Mary Hardin-Baylor, Human Performance Lab, Belton, TX

76513, USA. ${ }^{2}$ Dymatize Nutrition, Farmers Branch, TX 75234, USA. ${ }^{3}$ University of South Florida, Exercise \& Performance Nutrition Lab, Tampa, FL 33544

USA

Published: 19 November 2012

doi:10.1186/1550-2783-9-S1-P12

Cite this article as: Jones et al.: Evaluation of ingesting Dyma-Burn

Xtreme, a thermogenic dietary supplement, on hemodynamic and ECG

responses in healthy, young males and females. Journal of the

International Society of Sports Nutrition 2012 9(Suppl 1):P12.

Submit your next manuscript to BioMed Central and take full advantage of:

- Convenient online submission

- Thorough peer review

- No space constraints or color figure charges

- Immediate publication on acceptance

- Inclusion in PubMed, CAS, Scopus and Google Scholar

- Research which is freely available for redistribution

Submit your manuscript at www.biomedcentral.com/submit 